\title{
DETECTION OF GRAPEVINE (Vitis Vinifera) RESISTANT VARIETIES TO POWDERY MILDEW DISEASE BASED ON SSR-PCR MARKER.
}

\author{
Rojan Sh. Sulaiman ${ }^{*}$, Avesta Mohammed Ali ${ }^{* *}$ and Payman. A. A. Zibari ${ }^{*}$ \\ *Dept. of Horticultural, Collage of Agriculture Engineering Sciences, University of Duhok, \\ Kurdistan region-Iraq \\ ${ }^{* *}$ Scientific Research Center, College of Science, University of Duhok, Kurdistan region-Iraq
}

(Received: October 14, 2019; Accepted for Publication: January 8, 2020)

\begin{abstract}
Powdery mildew is a fungal disease caused by Erysiphe necator considered to be most important fungal diseases and causing loss of grapevine production. The use of molecular markers has been proposed to be the best method for identifying genes for resistance to powdery mildew which provides basic information in breeding programs. This study has been conducted at Scientific Research Caenter/College of Science/University of Duhok during the period (July 2018 to August 2019). Simple Sequence Repeat (SSR) Marker has been used to detect the powdery mildew by applying ten SSR markers for twenty cultivars of Vitis vinifera collected from Duhok vineyard and Directorate of Horticulture in Duhok City. Considered the useful markers as the guidelines for detecting the gene responsible for the resistance to powdery mildew, in this study all the varieties and land races that had been used to detect such a gene were some tested varieties (Chav Ga, Zaytoni, Tahlik, Tlifishak, Kishmish1, Kishmish2, Kishmish3, Payizi, Doshawi, Baytmoni, Bagerat2, Miskat Aswad, Ashqar Basrah) contain an 80, 90, 94,114 base pairs as a single band. At the same time not all varieties are powdery mildew due to absence of all alleles which make them a susceptible for powdery mildew infection.
\end{abstract}

KEY WORD: Grape vine, Powdery mildew, SSR Marker, Vitis vinifera

\section{INTRODUCTION}

G rape (Vitis vinifera L.) is an important and an economic fruit among the horticultural crops production grown worldwide, because of the numerous uses of its fruit benefit, producing wine, juice table grapes dried fruit and organic compounds and it is one of the oldest plants known to man grows virtually in most country(Aigrain, 1999; Alsaidi, 2000). The grapevines are widely planted in Duhok, Erbil and Sulaymaniyah governorates, where it grows due to suitable climatic condition and soils (Abdul-Qader \& Alsaidi, 2006; Al-Atrushi, 2009).

Powdery mildew is a common fungal disease of many monocotyledonous and dicotyledonous plant species and consider as the most widespread and destructive disease of grapevines (Gadoury et $a l . . .$, 2003). In a moderately temperate and humid climate, these ascomycete fungi cause severe yield losses in a wide range of crops (Panstruga et al., 2002). Erysiph necator the most known causative agent that causes this disease (Ficke $e t$ $a l .,, 2002)$. This came from studies of the disease on cultivars of the European grape, Vitis vinifera, which bears leaves and fruit that are highly susceptible to this disease .(Gadoury et al., , 2001; Scott et al.,, 2010).

A microsatellites are the favorite type of DNA markers, due to their properties enabling a wide range of applications, from cultivar identification and discrimination, to phylogenetics, parentage testing and pedigree reconstruction, for the

* A part of the first author's MSc thesis 
management of germplasm collections(Laucou et al., 2011; Sefc et al., 2000). Simple sequence repeat (SSR) markers are based on repeated sequences of one- to six-base core sequences (typically two to four), found interspersed in the genome, and it is particularly useful because of their; abundance in genomes, high degree of variability in the repeat sequence, and high reproducibility, so the use of microsatellite for grapevine genetics includes; the identification of cultivars, the relatedness of cultivars and the analysis of the parentage of crosses (Sefc, et al., 1997; Fundyga et al, 2002; This et al., 2004; Goto-Yamamoto, et al.,2006). The objective of the present study is to Screen grape yards varieties and land races characters for the resistance to Powdery Mildew and using SSR PCR markers as molecular technique for identification of Powdery Mildew resistance genes.

\section{MATERIALS AND METHODS}

\section{Samples collection:}

The leaves of twenty local cultivars of the genus Vitis (gawre xate, chav ga, zaytoni, tahlik, tli fishak, kishmish1, kishmish2, kishmish3, payizi, doshawi, bagerat2, miskat aswad, ashqar basrah, baytamoni, haft bar, Shahi Hindi, Dirawishi, Baladi, Kirkirana, Salami) were collected during (July-September 2018) from Duhok vineyard and Directorate of Horticulture in Duhok.

\section{DNA extraction:}

Genomic DNA was isolated from leaf samples according to CTAB (cethyltrimethyl ammonium bromide) extraction method described by (Weigand et al., 1993). Genomic DNA of all samples were run on $1 \%$ Agarose gel electrophoresis. The concentration and purity of DNA was determined using Nano drop spectrophotometric.

\section{Simple Sequence Repeats (SSR)}

In order to genotype the grapevine cultivars, ten primer pairs for microsatellite

(SSR) loci were used with their sequences and annealing temperature, were initially selected to perform this research as shown in (Table 1) (Veikondis, 2014). 
Table(1): list of SSR primers used in this study.

\begin{tabular}{|c|c|c|}
\hline Primer name & Primer sequence & To Annealing \\
\hline VVIV16 & $\begin{array}{l}\text { (F) 5'- ACA AAA GCG GAA ACG ATC GAA T -3' } \\
\text { (R) 5'- GAG AAG ACC TAT TTT TCC TGT GG -3' }\end{array}$ & $49^{\circ} \mathrm{C}$ \\
\hline VVIM93 & $\begin{array}{l}\text { (F) 5'- CAA CGT TTA TTG TAA GAG CCT C -3' } \\
\text { (R) 5'- GCT TAG CTT GCT AGA AAC TTG A -3' }\end{array}$ & $48^{\circ} \mathrm{C}$ \\
\hline VMC1A5 & $\begin{array}{l}\text { (F) 5'- TCA CAC AAT TCT CCC ATG AAA TAG -3' } \\
\text { (R) 5'- GAA CAA GTT GGC ATG TTG GTT A -3' }\end{array}$ & $48^{\circ} \mathrm{C}$ \\
\hline VMC3E5 & $\begin{array}{l}\text { (F) 5'- GAT TTG TCT TTA CAA GGC GTT C 3' } \\
\text { (R) 5'- GCC AGG AGA CTT GCT TTG TAT TT -3' }\end{array}$ & $49^{\circ} \mathrm{C}$ \\
\hline UDV047 & $\begin{array}{l}\text { (F) 5'- TGT ATG ATA ATC CAT AAT TGT C -3' } \\
\text { (R) 5'- GTA GGC ATG CTT GAC TTA TTC -3' }\end{array}$ & $45^{\circ} \mathrm{C}$ \\
\hline VMC8F4.2 & $\begin{array}{l}\text { (F) 5'- GCG TAA AGC ATA TTC AAG CAT T -3' } \\
\text { (R) 5'- GAA GTT AGC GCA GAT GAA AGA T -3' }\end{array}$ & $48^{\circ} \mathrm{C}$ \\
\hline VVIN16-CJVH & $\begin{array}{l}\text { (F) 5'- CCC GCC CTT CCT ATT TGT A -3' } \\
\text { (R) 5'- GAA GCC AAT GAA AGA AGA ATT AAC A -3' }\end{array}$ & $48^{\circ} \mathrm{C}$ \\
\hline VMC3E5(F-2) & $\begin{array}{l}\text { (F) 5'- GAT TTG TCT TTA CAA GGC GTT C -3' } \\
\text { (R) 5'- GCC AGG AGA CTT GCT TTG TAT TT -3' }\end{array}$ & $49^{\circ} \mathrm{C}$ \\
\hline VMC8B5 & $\begin{array}{l}\text { (F) 5'- AAA GGA GAC ATC TGC ATC AT -3' } \\
\text { (R) 5'- GCC TTG ATC TTC CTT CTA AT -3' }\end{array}$ & $45^{\circ} \mathrm{C}$ \\
\hline VVC62 & $\begin{array}{l}\text { (F) 5'- TGG GAT TAA CAC GGA CTT CTT -3' } \\
\text { (R) 5'- GTG GCT AAG CTA GCC CTG TA -3' }\end{array}$ & $50^{\circ} \mathrm{C}$ \\
\hline
\end{tabular}

\section{Polymerase chain reaction:}

The PCR mix had the following composition; $12.5 \mu \mathrm{l}$ of master mix (GoTaq, Promega) -; $2 \mu 1$ of each forward and reverse primers $(6 \mathrm{pmol} / \mu \mathrm{l}$ ); $3 \mu \mathrm{l}$ of DNA sample $(25-50 \mathrm{ng} / \mu \mathrm{l})$ the volume was completed to $25 \mu \mathrm{l}$ by adding Deionized distill water to a final volume, After the selection of the optimal temperature for each primer set (as clarify in Table 1), the PCR reactions were performed on a thermo cycler (Applied Bio systems) (Table2) (Riaz et al.,, 2011).

Table (2): The thermo cycler program

\begin{tabular}{ll}
\hline $94^{\circ} \mathrm{C} \rightarrow \mathbf{5}$ minutes & \\
\hline $94^{\circ} \mathrm{C} \rightarrow 1$ minute & $\times 35$ cycles \\
& ${ }^{*} T^{\circ}$ annealing $(50-60$ as shown in table 1$) \rightarrow 30$ seconds \\
$72^{\circ} \mathrm{C} \rightarrow 30$ seconds & \\
\hline $72^{\circ} \mathrm{C} \rightarrow 12$ minutes \\
\hline
\end{tabular}

$* \mathrm{~T}^{\mathrm{o}}$ Annealing temperature of primer

* A part of the first author's MSc thesis 
The amplification product was analyzed in a

$2 \%$ agarose gel, and then stained in Ethidium Bromide.

\section{Results and discussion:}

Genomic DNA isolation:

The procedure used for genomic DNA extraction in this study followed (Weigand et al., 1993) and was found to produce efficient yields of DNA sample for PCR amplification. The amount and concentration of isolated DNA from studied cultivars ranged from 66 - $455 \mathrm{ng}$ $/ \mu 1$ with a purity of 1.4-1.8. The molecular weight of genomic DNA sample was estimated using $1 \%$ agarose gel electrophoresis (Figure 1).

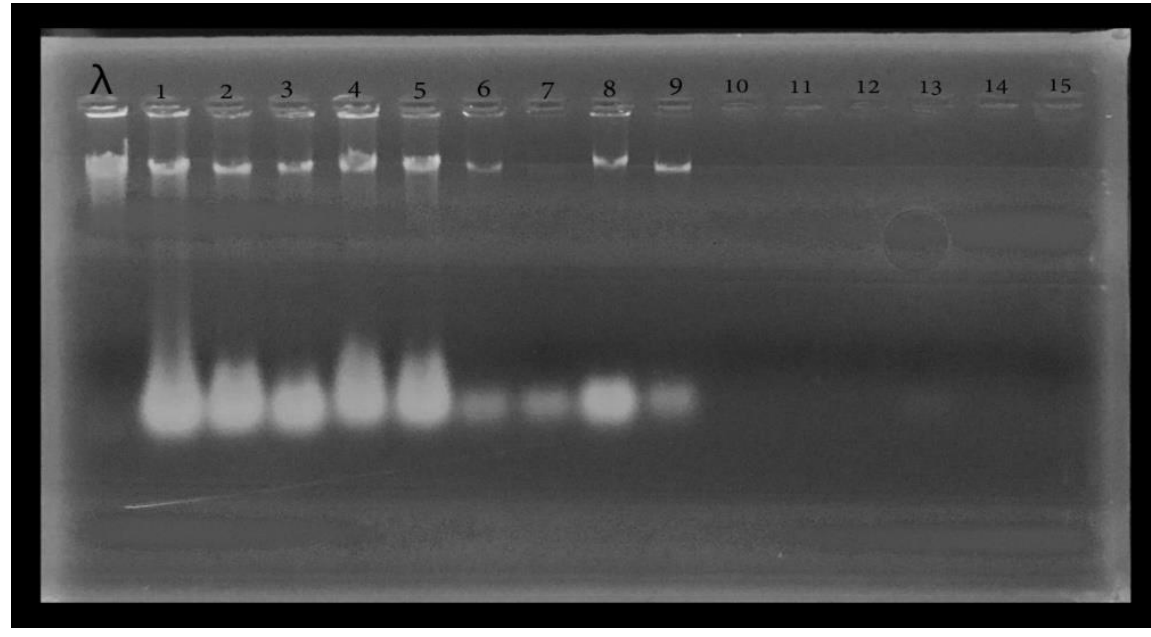

Fig.(1): Extracted genomic DNA of Vitis cultivars run on 1\% Agarose gel electrophoresis at 3-4 v/cm.

\section{SSR marker Analysis}

Amplified microsatellite loci were scored in 20 Vitis varieties and in order to obtain reproducible results, several modifications were made to optimize PCR reaction conditions; these included annealing temperatures to increase the efficiency and eliminate some of unspecific products. PCR reactions were then prepared and successful results were obtained with the ten primers (VMC8B5, VVIM93, VVIV16, VMC1A5, UDV047, VMC3E5, VMC8F4.2, VVIN16-CJVH, VMC3E5 (F-2) and VVC62).

In the (Figure 2): illustrates that fifteen Vitis varieties amplified at VMC8B5 microsatellite locus shows the result of base pair size 60 to 110 , by which the homozygous status of a certain SSR locus can be established.

* A part of the first author's MSc thesis

rojan.barwary@gmail.com, avesta.ali@uod.ac, _ pzibari@gmail.com 


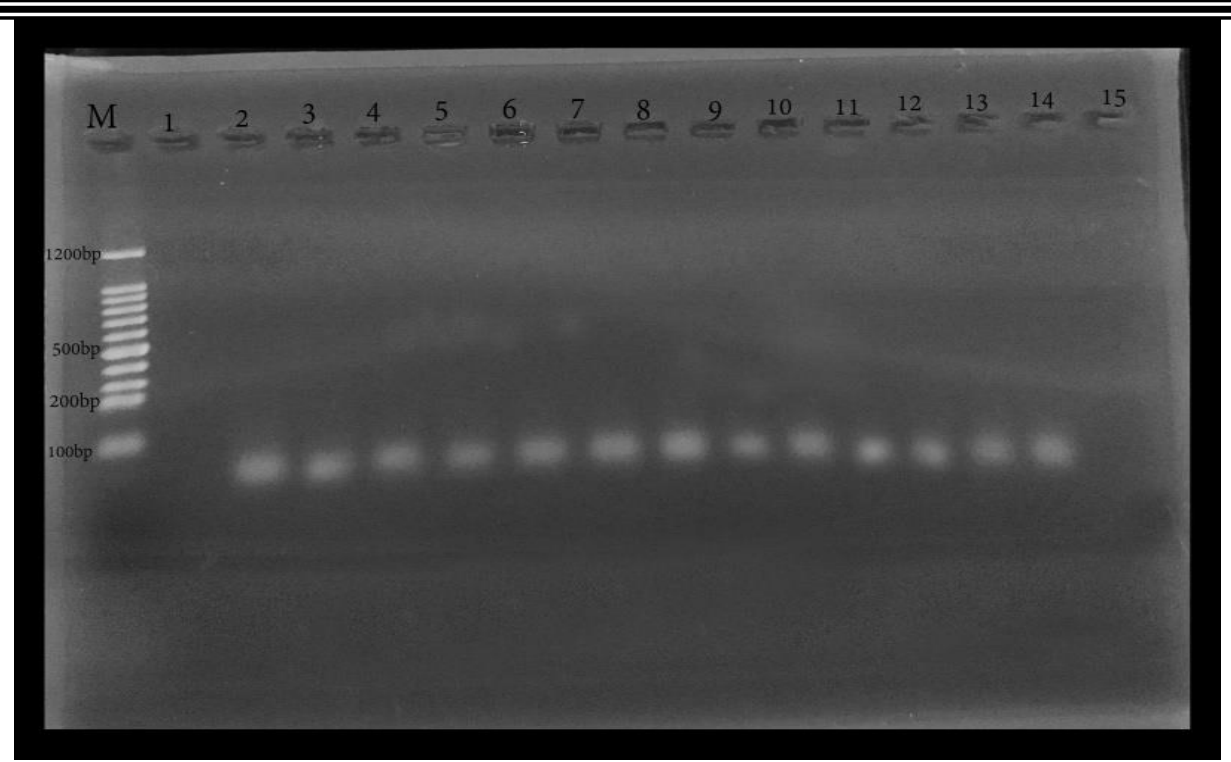

Fig. (2): Amplified PCR products obtained with microsatellite primer (VMC8B5) in vitis vinifera (grape) varieties, run on $2 \%$ Agarose gel electrophoresis at 3-4 v/cm, M represents DNA Marker (100bp). 1.Gawre Xate 2.Chav Ga 3.Zaytoni 4.Tahlik 5.Tli Fishak 6.Kishmish1 7.Kishmish2 8.Kishmish3 9.Payizi 10.Doshawi 11.Bagerat2 12.Miskat Aswad 13.Ashqar Basrah 14.Baytamoni 15.Haft Bar.

In (Figure 3) clarify that fifteen Vitis varieties amplified at VMC1A5 microsatellite locus, shows the result of base pair size 60 to 80, by which the homozygous status of a certain SSR locus can be established.

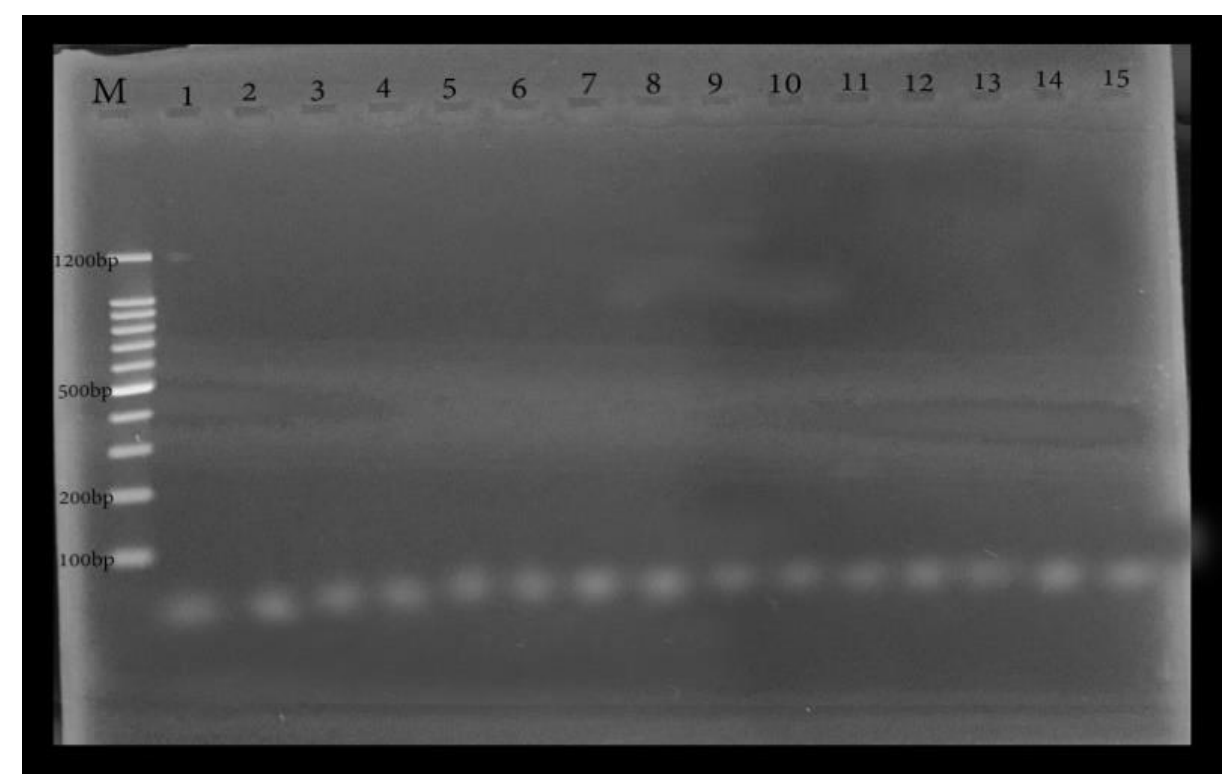

Fig. (3): Amplified PCR products obtained with microsatellite primer (VMC1A5) in vitis vinifera (grape) varieties, run on $2 \%$ Agarose gel electrophoresis at 3-4 v/cm, M represents DNA Marker (100bp). 1.Gawre Xate 2.Chav Ga 3.Zaytoni 4.Tahlik 5.Tli Fishak 6.Kishmish1 7.Kishmish2 8.Kishmish3 9.Payizi 10.Doshawi 11.Bagerat2 12.Miskat Aswad 13.Ashqar Basrah 14.Baytamoni 15.Haft Bar.

\footnotetext{
* A part of the first author's MSc thesis
} 
In the locus VVC62, all Vitis varieties used in this study do not show any bands, it lack this allele Figure (4).

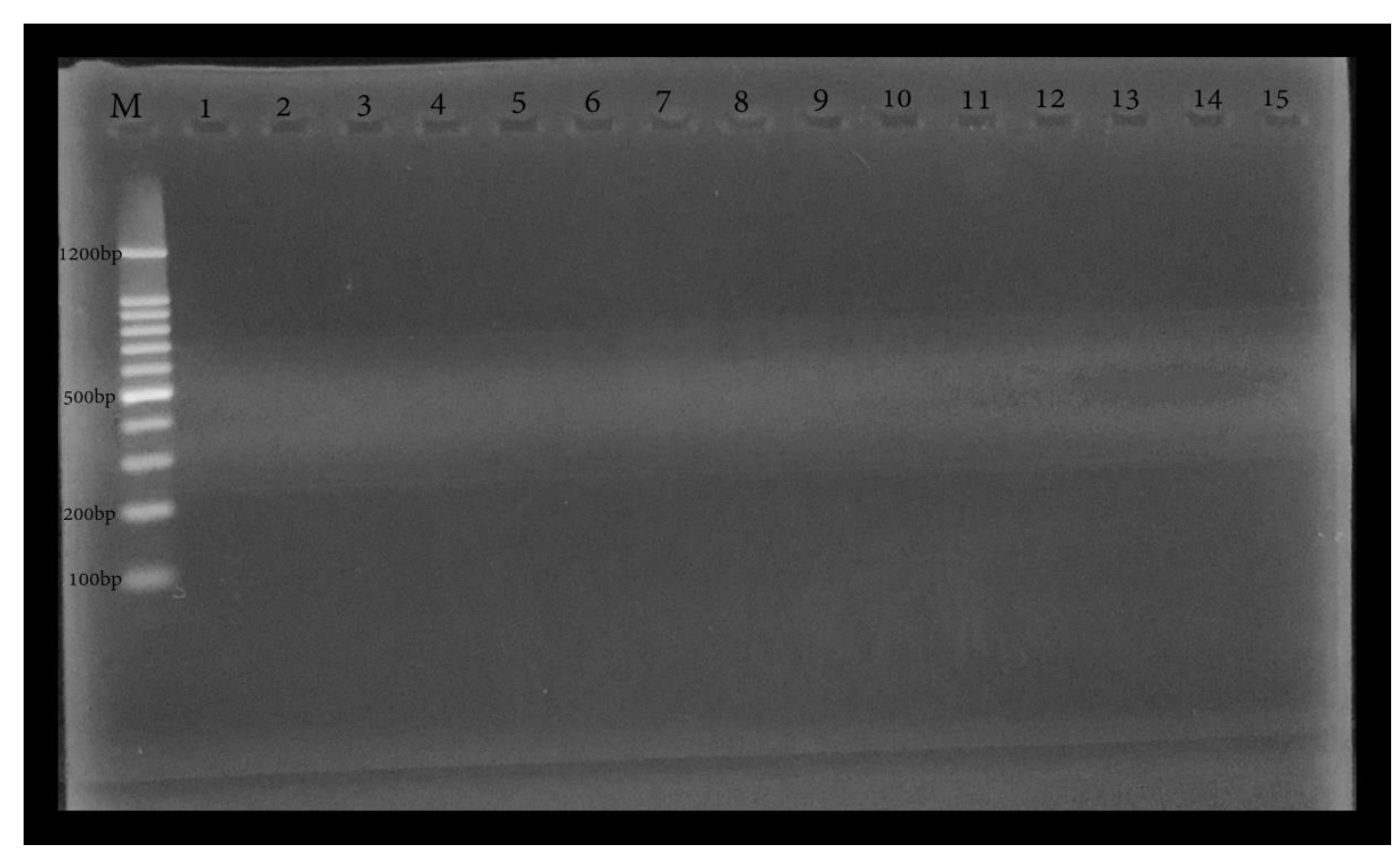

Fig. (4): Amplified PCR products obtained with microsatellite primer (VVC62) in vitis vinifera (grape) varieties, run on $2 \%$ Agarose gel electrophoresis at 3-4 v/cm, M represents DNA Marker (100bp). 1.Gawre Xate 2.Chav Ga 3.Zaytoni 4.Tahlik 5.Tli Fishak 6.Kishmish1 7.Kishmish2 8.Kishmish3 9.Payizi 10.Doshawi 11.Bagerat2 12.Miskat Aswad 13.Ashqar Basrah 14.Baytamoni 15.Haft Bar.

Table (3): Size of alleles at 10 microsatellites loci, in twenty grapevine cultivars

\begin{tabular}{|c|c|c|c|c|c|c|c|c|c|c|}
\hline \multirow[t]{2}{*}{ Cultivar } & \multicolumn{10}{|c|}{ SSR Primers } \\
\hline & VVIV16 & VMC3E5 & VMC8B5 & VVIM93 & VMC1A5 & $\begin{array}{l}\text { VMC8 } \\
\text { F4.2 }\end{array}$ & $\begin{array}{l}\text { VVIN1 } \\
6- \\
\text { CJVH }\end{array}$ & $\begin{array}{l}\text { UDV04 } \\
7\end{array}$ & $\begin{array}{l}\text { VMC3E5(F- } \\
\text { 2) }\end{array}$ & VVC62 \\
\hline Gawre Xate & -------- & ------- & ------- & $105 / 105$ & $60 / 60$ & ------ & -------- & $60 / 60$ & $85 / 85$ & -------- \\
\hline Chav Ga & $100 / 100$ & $110 / 110$ & $85 / 85$ & $100 / 100$ & $60 / 60$ & (------ & |------- & $60 / 60$ & $90 / 90$ & $\begin{array}{l}---\cdot--- \\
\end{array}$ \\
\hline Zaytoni & $100 / 100$ & $110 / 110$ & $85 / 85$ & $110 / 110$ & $60 / 60$ & ------ & -------- & $60 / 60$ & $100 / 100$ & -------- \\
\hline Tahlik & $100 / 100$ & $110 / 110$ & $100 / 100$ & $110 / 110$ & $65 / 65$ & ------ & -------- & $60 / 60$ & $95 / 95$ & -------- \\
\hline Tli Fishak & $100 / 100$ & $110 / 110$ & $100 / 100$ & $110 / 110$ & $65 / 65$ & $-\cdots----$ & ------- & $60 / 60$ & $105 / 105$ & ------- \\
\hline Kishmish1 & $100 / 100$ & $110 / 110$ & $110 / 110$ & $110 / 110$ & $65 / 65$ & $\begin{array}{ll}------ \\
\end{array}$ & -------- & $60 / 60$ & $105 / 105$ & -------- \\
\hline Kishmish2 & $100 / 100$ & $110 / 110$ & $110 / 110$ & $105 / 105$ & $70 / 70$ & ------ & -------- & $60 / 60$ & 105/105 & -------- \\
\hline Kishmish3 & $100 / 100$ & $100 / 100$ & $110 / 110$ & $65 / 65$ & $75 / 75$ & 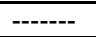 & |------ & $60 / 60$ & $90 / 90$ & ------- \\
\hline Payizi & $100 / 100$ & $100 / 100$ & $105 / 105$ & $65 / 65$ & $75 / 75$ & 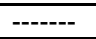 & - - & $60 / 60$ & $90 / 90$ & ------- \\
\hline Doshawi & $100 / 100$ & $100 / 100$ & $110 / 110$ & $65 / 65$ & $75 / 75$ & ------ & -------- & $60 / 60$ & $105 / 105$ & ------- \\
\hline Bagerat2 & $100 / 100$ & $100 / 100$ & $90 / 90$ & $65 / 65$ & $75 / 75$ & ------ & ------- & $65 / 65$ & $85 / 85$ & ------- \\
\hline Miskat Aswad & $100 / 100$ & $98 / 98$ & $90 / 90$ & $65 / 65$ & $75 / 75$ & ------- & -------- & $60 / 60$ & $100 / 100$ & -------- \\
\hline Ashqar Basrah & $100 / 100$ & $98 / 98$ & $100 / 100$ & $65 / 65$ & $75 / 75$ & ------- & -------- & $60 / 60$ & $90 / 90$ & -------- \\
\hline Baytamoni & $105 / 105$ & $98 / 98$ & $100 / 100$ & $65 / 65$ & $75 / 75$ & ------- & -------- & $60 / 60$ & $100 / 100$ & -------- \\
\hline Haft Bar & ----- & |---------- & ---------- & $65 / 65$ & $70 / 70$ & $65 / 65$ & |------ & $60 / 60$ & $90 / 90$ & ------- \\
\hline Shahi Hindi & $100 / 100$ & $95 / 95$ & $60 / 60$ & $65 / 65$ & $80 / 80$ & $65 / 65$ & $65 / 65$ & $60 / 60$ & $75 / 75$ & |------- \\
\hline Dirawishi & $98 / 98$ & $95 / 95$ & $70 / 70$ & $65 / 65$ & $80 / 80$ & $65 / 65$ & $65 / 65$ & $60 / 60$ & $75 / 75$ & -------- \\
\hline Baladi & $98 / 98$ & $95 / 95$ & $80 / 80$ & $65 / 65$ & $80 / 80$ & $65 / 65$ & $65 / 65$ & $60 / 60$ & $80 / 80$ & $\begin{array}{l}------- \\
\end{array}$ \\
\hline Kirkirana & $98 / 98$ & $98 / 98$ & $90 / 90$ & $65 / 65$ & $80 / 80$ & $65 / 65$ & $65 / 65$ & $65 / 65$ & $85 / 85$ & -------- \\
\hline Salami & ----- & ----- & -------- & $65 / 65$ & $80 / 80$ & $65 / 65$ & $65 / 65$ & $65 / 65$ & $85 / 85$ & -------- \\
\hline
\end{tabular}

* A part of the first author's MSc thesis

rojan.barwary@gmail.com, avesta.ali@uod.ac, $\quad$ pzibari@gmail.com 
In this study, limited SSR primers were utilized related to Powdery mildew resistance genes in Duhok Governorate and many landraces types were choose to be investigated and powdery mildew gene detection.

According to previous findings the bellow results can be summarized:

Some tested varieties (Chav Ga, Zaytoni, Tahlik, Tlifishak, Kishmish1, Kishmish2, Kishmish3, Payizi, Doshawi, Baytmoni, Bagerat2, Miskat Aswad, Ashqar Basrah) contain an $80,90,94,114$ base pairs as a single band. These results agree with the Veikondis (2014) who mentioned that using SSR profile in grape varieties the allele of gene resistance to powdery mildew was $81,90,94,114$ allele.

To gain all powdery mildew resistance genes, in should inherited the multiple binding site and produce complex SSR profile Veikondis (2014), So the obtained results revealed that the genes give the partial resistance to powdery mildew.

At the same time, not all varieties are powdery mildew due to absence of all alleles which make them a susceptible for powdery mildew infection.

The identification of an overlapping resistance region from different genetic backgrounds is of significant importance to grape breeders, as well as to molecular biologists studying host-pathogen interactions, the evolution of resistance mechanisms, and comparative analysis of key resistance genes.

The genetic base of resistance to powdery mildew and other grape vine diseases originates from Vitis species which are natural sources of resistance, mainly deriving from North-America and more recently from the Far East. Most of them confer varying levels of partial resistance.

The severity of powdery mildew pressure could vary from year to year due to a varying composition of strains, (Montarry et al., 2008) reported a strong relationship between disease severity and the genetic composition of $E$. necator populations, so investigation of the larger number of genes and more varieties and land races in order to have wider aspect for analysis and detect the resistance genes.

This work is the first kind in Kurdistan region where evaluate the gene resistance of powdery mildew among local variety of grape in Duhok. The work provides further evidence of the strong predictive power of marker assisted to powdery mildew.

32 rojan.barwary@gmail.com, avesta.ali@uod.ac,

\section{CONCLUSION}

In conclusion these varieties are susceptible to the powdery mildew, and for the recommendation more varieties and more primers need to be used in order to detect this gene, which is important because it effects the crop production and grape plant as well.

\section{REFERENCES}

- Abdul-Qader, S. M., \& Alsaidi, I. H. (2006). Effect of Training System, Canopy Management and Dates on the Yield and Quality of Grapevines $\mathrm{cv}$.= Taifi '(Vitis vinifera L.) Under non Irrigated Condition. M. Sc. Thesis, College of Agric. Univ. of Duhok, Iraq. pp: 40-55.

- Aigrain, P. (1999). Conjoncture vitivinicole mondiale. Bull. OIV, 817(81), 228-240.

- Al-Atrushi, S. M. (2009). Effect of eyes number and foliar spray of Potassium and Copper on the vegetative growth, productivity and quality of Grape (Vitis vinifera L.) cv. Zark under nonirrigated condition. Ph. D. Thesis. The Council of the College of Agriculture and Forestry ....

- Alsaidi, I. (2000). Grape production: Mosul university press.

- Ficke, A., Gadoury, D. M., \& Seem, R. C. (2002). Ontogenic resistance and plant disease management: A case study of grape powdery mildew. Phytopathology, 92(6), 671-675.

- Fundyga, R. E., Lott, T. J., \& Arnold, J. (2002). Population structure of Candida albicans, a member of the human flora, as determined by microsatellite loci. Infection, Genetics and Evolution, 2(1), 57-68.

- Gadoury, D. M., Seem, R. C., Ficke, A., \& Wilcox, W. F. (2003). Ontogenic resistance to powdery mildew in grape berries. Phytopathology, 93(5), 547-555.

- Gadoury, D. M., Seem, R. C., Pearson, R. C., Wilcox, W. F., \& Dunst, R. M. (2001). Effects of powdery mildew on vine growth, yield, and quality of concord grapes. Plant disease, 85(2), 137-140.

- Goto-Yamamoto, N., Mouri, H., Azumi, M., \& Edwards, K. J. (2006). Development of grape microsatellite markers and microsatellite analysis including oriental cultivars. American

\footnotetext{
* A part of the first author's MSc thesis
}

$32.10 j a n$ barwary@gmail.com, avesta.ali@uodac,

pzibari@gmail.com 
journal of enology and viticulture, 57(1), 105108.

- Laucou, V., Lacombe, T., Dechesne, F., Siret, R., Bruno, J.-P., Dessup, M., Roux, C. (2011). High throughput analysis of grape genetic diversity as a tool for germplasm collection management. Theoretical and Applied Genetics, 122(6), 1233-1245.

- Montarry, J., Cartolaro, P., Delmotte, F., Jolivet, J., \& Willocquet, L. (2008). Genetic structure and aggressiveness of Erysiphe necator populations during grapevine powdery mildew epidemics. Appl. Environ. Microbiol., 74(20), 6327-6332.

- Panstruga, R., \& Schulze-Lefert, P. (2002). Live and let live: insights into powdery mildew disease and resistance. Molecular plant pathology, 3(6), 495-502.

- Riaz, S., Tenscher, A., Ramming, D., \& Walker, M. (2011). Using a limited mapping strategy to identify major QTLs for resistance to grapevine powdery mildew (Erysiphe necator) and their use in marker-assisted breeding. Theoretical and Applied Genetics, 122(6), 1059-1073.

- Scott, E., Dambergs, R., \& Stummer, B. (2010). Fungal contaminants in the vineyard and wine quality Managing wine quality (pp. 481-514): Elsevier.
- Sefc, K., Lopes, M., Lefort, F., Botta, R., Roubelakis-Angelakis, K., Ibanez, J., . . . Steinkellner, H. (2000). Microsatellite variability in grapevine cultivars from different European regions and evaluation of assignment testing to assess the geographic origin of cultivars. Theoretical and Applied Genetics, 100(3-4), 498-505.

- Sefc, K. M., Steinkellner, H., Wagner, H., Glössl, J., \& Regner, F. (1997). Application of microsatellite markers to parentage studies in grapevine. Vitis, 36(4), 179-183.

- This, P., Jung, A., Boccacci, P., Borrego, J., Botta, R., Costantini, L., Ferreira-Monteiro, F. (2004). Development of a standard set of microsatellite reference alleles for identification of grape cultivars. Theoretical and Applied Genetics, 109(7), 1448-1458.

- Veikondis, R. (2014). Genetic characterisation of fungal disease resistance genes in grapevine using molecular marker technology. Stellenbosch: Stellenbosch University.

- Weigand, F., Baum, M., \& Udupa, S. (1993). DNA molecular marker techniques. Technical Manual No. 20: ICARDA

* A part of the first author's MSc thesis

rojan.barwary@gmail.com, avesta.ali@uod.ac, $\quad$ pzibari@gmail.com 